\title{
The role of calcium in drought stress response induced through antioxidant activity in oil palm (Elaeis guineensis Jacq.) seedlings
}

\author{
Peran kalsium dalam induksi respons bibit kelapa sawit (Elaeis guineensis Jacq.) terhadap kekeringan \\ melalui aktivitas antioksidan \\ Endah NURWAHYUNI ${ }^{\left.1)^{*}\right)}$ \& Eka Tarwaca Susila PUTRA ${ }^{2)}$ \\ 1) Batang-Research and Assessment Installation for Agricultural Technology (Batang-RAIAT) - Central Java Assessment \\ Institute for Agricultural Technology (CJ-AIAT) - Indonesian Agency for Agricultural Research and Development \\ (IAARD), Jl. Soekarno - Hatta KM.26 No.10, Bergas, Semarang 50552 \\ 2) Department of Agronomy, Faculty of Agriculture, Gadjah Mada University, Jl. Flora, Bulaksumur, Yogyakarta 55281
}

Received 22 March 2021 / Accepted 30 April 2021

\begin{abstract}
Abstrak
Produktivitas kelapa sawit di Indonesia menghadapi tantangan terkait kekeringan yang terjadi sepanjang musim kemarau. Kalsium dikenal sebagai unsur yang berperan dalam menentukan respons ketahanan tanaman terhadap kekeringan melalui aktivitas biokimia. Penelitian ini bertujuan untuk mengetahui kontribusi kalsium dalam mekanisme biokimia yang melibatkan berbagai antioksidan. Perlakuan disusun secara faktorial $3 \times 4$ dalam rancangan desain petakterbagi. Faktor pertama adalah pemberian kalsium dengan dosis $0 \mathrm{~g}$ (kontrol/tanpa kalsium); $0,04 \mathrm{~g} ; 0,08 \mathrm{~g}$; dan 0,12 g per tanaman. Faktor kedua adalah intensitas cekaman kekeringan mengacu metode Fraction Transpirable Soil Water (FTSW) yang terdiri dari FTSW 1 (kontrol/kapasitas lapang), FTSW 0,35 (cekaman moderat), dan FTSW 0, 15 (cekaman berat) dengan lama intensitas satu minggu. Pemberian kalsium dilakukan secara ring placement pada bibit berumur empat bulan yang ditanam pada polibag berukuran $40 \times 40 \mathrm{~cm}$ dengan media tanam berupa tanah alfisol yang diberi perlakuan kekeringan dua bulan kemudian selama tiga minggu. Hasil penelitian menunjukkan bahwa kalsium menginduksi respons tanaman terhadap kekeringan melalui peningkatan aktivitas superoksida dismutase (SOD), penurunan konsentrasi hidrogen peroksida $\left(\mathrm{H}_{2} \mathrm{O}_{2}\right)$, dan penurunan konsentrasi malondialdehid (MDA). Penelitian ini menyimpulkan bahwa kalsium merupakan unsur esensial yang berperan dalam menurunkan dampak kekeringan pada bibit kelapa sawit melalui perubahan aktivitas biokimia yang diatur oleh enzim antioksidan.
\end{abstract}

[Kata kunci: antioksidan enzimatik, $\mathrm{H}_{2} \mathrm{O}_{2}, \mathrm{MDA}$, SOD]

\footnotetext{
${ }^{*}$ correspondence author: nurwahyuni.endah@gmail.com
}

\begin{abstract}
Oil palm productivity in Indonesia faces challenges related to drought that occur during the dry season. Calcium is an element that plays a role in determining the response of plant resistance to drought through biochemical activity. This study aims to determine the contribution of calcium in biochemical mechanisms involving various antioxidants. The treatment was arranged in factorial of $3 \times 4$ in a split-plot design. The first factor was calcium dosage, which consisted of $0 \mathrm{~g}$ (control/without calcium), $0.04 \mathrm{~g}, 0.08 \mathrm{~g}$, and 0.12 $\mathrm{g}$ of calcium per plant. The second factor was the intensity of drought stress, referred as the Fraction of Transpirable Soil Water (FTSW) at 1 (control/field capacity), 0.35 (moderate drought), and 0.15 (severe drought) with a week duration of intensity. Calcium was applied in a ring placement on four-month-old seedlings planted in $40 \times 40 \mathrm{~cm}$ polybags with alfisol soil planting medium and given drought treatment two months later for three weeks. The results showed that calcium could induce plant response to drought through the increase in superoxide dismutase (SOD) activity, the decrease in hydrogen peroxide $\left(\mathrm{H}_{2} \mathrm{O}_{2}\right)$ concentration, and the decrease in malondialdehyde (MDA) concentration. The study concluded that calcium is an essential element used to reduce the effects of drought on oil palm seedlings through the change of biochemical activities regulated by enzymatic antioxidants.
\end{abstract}

[Keywords: enzymatic antioxidant, $\mathrm{H}_{2} \mathrm{O}_{2}, \mathrm{MDA}$, SOD]

\section{Introduction}

Oil palm (Elaeis guineensis Jacq.) is a plant sensitive to drought stress related to its root system (Safitri et al., 2018). Data from the Ministry of Agriculture, Republic of Indonesia (2017) 
suggested that the impact of drought in Indonesia and Malaysia has reduced palm oil production by $26.30 \%$. Drought stress in oil palm caused a decrease in the production rate of leaf midrib, sex ratio, and the number of fruit bunches. Moreover, drought stress also induces an increase in flower abortion/miscarriage, bunch failure, which caused a decrease in yield by delayed harvesting time (Darlan et al., 2016).

The growth response, biomass distribution, nutrient concentration, morphological, and physiological of oil palm are more influenced by drought stress because of the relationship between physiological and biochemical parameters in oil palm (Cheng-xu et al., 2011). These responses include decreased photosynthesis activity, chloroplast activity (Ashraf \& Harris, 2013; Shekari et al., 2015), and photosystem II activity (Meng et al., 2016). Moreover, the drought stress also increased oxygen consumption through the Mehler-reaction, peroxidase and photorespiration, respiration, translocation, ion uptake, nutrient metabolism and growth promoters (Aroca, 2012), changes in the shape of lipid matter and its arrangement in the plasma membrane (Mckersie et al., 1996), and the accumulation of osmoprotectants such as sugar alcohols, amino acids, and organic acids (Ahmad et al., 2012). The degree of stress experienced by plants depends on several factors such as intensity and duration of stress and plant genotype (Shekari et al., 2015).

Improvement of plant physiological resistance to drought stress can be made by adding various elements, including boron, silica, and calcium. Boron could induce physiological resistance of oil palm seedlings to drought stress by increasing leaf greenness, width of stomatal aperture, and photosynthetic activity (Putra et al., 2015). While, the application of bio-silica has been shown to give a positive response by increasing nitrate reductase activity in oil palm seeds experienced by drought (Amanah et al., 2019). In Indonesia, oil palm is cultivated in an area with lower $\mathrm{pH}$ soil due to the washing of alkaline cations. Calcium deficiency is rarely found but can occur in soils with low base saturation or high acid deposit levels (Liebenberg et al., 2020). Calcium is known to have a role in overcoming biotic and abiotic stresses experienced by plants, including drought. $\mathrm{Ca}^{2+}$ ions function as transduction signals that convey stress signals from membranes into cells and induce various biochemical activities to produce several compounds in response to stress (Ahmad et al., 2012). Calcium has been considered to have a role in modifying stress-induced reactive oxygen species metabolism (Zhu, 2016), accumulating compatible osmolytes, and increasing antioxidant activities (Naeem et al., 2017). Calcium performs as a secondary messenger regulating ions, especially $\mathrm{K}^{+}$ions found in the closed stomata (Laanemets et al., 2013). This study aimed to provide evidence that calcium can repair drought stress effects through enzymatic and non- enzymatic antioxidant activity and find how much calcium is needed for optimum antioxidant production at each degree of dryness.

\section{Materials and Methods}

\section{Plant materials and experimental design}

A field experiment was conducted in August 2017 - May 2018 on seedlings nursery in Prambanan District, Sleman Regency, Yogyakarta, using Avros oil palm seedlings cultivated in polybags containing alfisol soil. Biochemical analysis was conducted in May - July 2018 at the Joint Facility Laboratory, Faculty of Biology, University of Gadjah Mada, Yogyakarta. The experiment was arranged according to the two factorial split-plot design. The first factor was drought stress which consisted of Fraction Transpirable Soil Water (FTSW) 1 (control/field capacity), FTSW 0.35 (moderate drought), and FTSW 0.15 (severe drought). The second factor was calcium $\left(\mathrm{CaSO}_{4}\right)$ application which consisted of $0 \mathrm{~g}$ (control), $0.04 \mathrm{~g}, 0.08 \mathrm{~g}$, and $0.12 \mathrm{~g}$ per plant. Calcium was applied in a ring placement on four-month-old seedlings planted in $40 \times 40 \mathrm{~cm}$ polybags with alfisol soil planting medium. Drought treatment was carried out for three weeks when the seedlings were six months old or two months after calcium application. Each treatment combination was consisted of nine plants repeated three times.

\section{Drought measurement}

Drought status was monitored by measuring the content of soil water. Polybags were weighed according to the soil capacity. The polybags were then weighed every day without watering it until they reached the drought treatment weight. The first sampling was carried out as the initial parameter drought. The drought stress was continued by adding water according to the FTSW weight on the first day until it returned to the target weight. The second sampling was carried out seven days later. The time was determined as the end of drought stress treatment. The fraction value of transpirable soil water (FTSW) is referred to as the method proposed by Ray \& Sinclair (1998). Leaf water potential $\left(\Psi_{\mathrm{w}}\right)$ was measured using a pressure chamber instrument model 1000.

\section{Free radicals and antioxidant measurement}

The $\mathrm{H}_{2} \mathrm{O}_{2}$ content was measured by Spectrophotometry developed by Alexieva et al. (2001). The $0.5 \mathrm{~g}$ crushed leaves, $5 \mathrm{ml} 0.1 \%$ (w/v) trichloroacetic acid (TCA) (for homogenization), $0.5 \mathrm{~mL}$ supernatant, $0.5 \mathrm{~mL}$ of $100 \mathrm{mM}$ potassium phosphate buffer, and $2 \mathrm{~mL}$ potassium iodide (KI) reagent $\left(1 \mathrm{M} \mathrm{KI}\right.$ in $\mathrm{H}_{2} \mathrm{O}$ ) were added to the test tube sequentially. Samples were put in a dark place for one hour. The samples were then inserted into the cuvette. The absorbance can be read at a $390 \mathrm{~nm}$ wavelength. For the standard, $0.1 \%$ TCA was used. 
The content of $\mathrm{H}_{2} \mathrm{O}_{2}$ calculated using an equation from the standard $\mathrm{H}_{2} \mathrm{O}_{2}$ curve known for its concentration.

Malondialdehyde (MDA) content was determined by the thiobarbituric acid (TBA) method proposed by Cheng-xu et al. (2011). About $1 \mathrm{~g}$ of plant leaves were crushed and homogenized with $2 \mathrm{~mL}$ TCA solution $0.1 \%(\mathrm{w} / \mathrm{v})$. Then, added $1.5 \mathrm{~mL}$ of the solution then centrifuged at 15000 $\mathrm{rpm}$ for $10 \mathrm{~min}$. Moreover, $0.5 \mathrm{~mL}$ supernatant was added to $1.5 \mathrm{~mL}$ of $0.5 \%(\mathrm{w} / \mathrm{v})$ TBA in a $20 \%$ $(\mathrm{w} / \mathrm{v})$ TCA. The mixture was shaken and then incubated in a water bath at $90{ }^{\circ} \mathrm{C}$ for $20 \mathrm{~min}$. The test tube was put into a beaker glass containing ice and centrifuged at $10.000 \mathrm{rpm}$ for $5 \mathrm{~min}$. Lastly, the supernatant was inserted into the cuvette and measured its absorbance at a wavelength of 532 and $600 \mathrm{~nm}$. MDA was calculated using the absorption coefficient of $155 \mathrm{mM}^{-1} \mathrm{~cm}^{-1}$. A $0.1 \%$ (w/v) TCA was used as blank. The MDA content was calculated using the formula below (1):

$$
\text { MDA content }=\frac{\left(\frac{\text { Difference of absorbance } 532 \mathrm{and} 600 \mathrm{~nm}}{\left(\frac{155 \mathrm{mM}}{\mathrm{cm}}\right) 106 \mathrm{~nm}}\right)}{\text { Fresh weight of leaves }}(1)
$$

Relative Electrolyte Leakage (REL) was determined according to the Dionisio-Sese \& Tobita (1998) method with minor modifications. As many as 10-20 sheets of leaf samples were punched using a paper hole and washed with distilled water three times. The samples were put into a test tube and placed at $25^{\circ} \mathrm{C}$ for 4 hours. The samples were added with $15 \mathrm{~mL}$ of distilled water then covered and stored at $10{ }^{\circ} \mathrm{C}$ for 24 hours. Furthermore, the samples were measured using an EC meter as the initial EC $\left(\mathrm{EC}_{0}\right)$. Lastly, the leaf samples were heated in an autoclave for $15 \mathrm{~min}$ at a temperature of $121^{\circ} \mathrm{C}$ and cooled to $25^{\circ} \mathrm{C}$ then the final $\mathrm{EC}\left(\mathrm{EC}_{1}\right)$ was measured.

Superoxide (SOD) activity was measured by the pyrogallol autoxidation method according to Marklund \& Marklund (1974). About $50 \mathrm{mM}$ buffer Tris- $\mathrm{HCl}$ pH 8.2 with one mM EDTA was used as the reaction medium, then added $40-60 \mathrm{mg}$ protein. The sample was extracted, mixed with 100 $10.2 \mathrm{mM}$ pyrogallol (dissolved in $50 \mathrm{mM}$ PPB $\mathrm{pH}$ $6.5)$ to start the reaction, and monitored at $420 \mathrm{~nm}$ the decrease in pyrogallol absorbance.

The total phenolic content was observed according to Ahmad et al. (2015). The $3^{\text {rd }}$ leaf was incubated at $40{ }^{\circ} \mathrm{C}$ for 48 hours. The $50 \mathrm{mg}$ of incubated leaves were mashed and put into a test tube. The tube was added with $0.4 \mathrm{ml}$ of FolinCiocalteu's phenol reagent and then left for 5-8 min. Moreover, it was added with $4 \mathrm{~mL}$ of $7 \%$ $\mathrm{Na}_{2} \mathrm{CO}_{3}(\mathrm{w} / \mathrm{v})$ and filtered using filter paper. The mixture was put into a $10 \mathrm{~mL}$ measuring flask, then added with aquabidest up to $10 \mathrm{~mL}$, and stands for 2 hours. Lastly, it was put into the cuvette to read the absorbance at $765 \mathrm{~nm}$ using 21D Spectronic, and aquabidest was used as blank (Rohman, 2007).
The total phenolic content calculated using the equation of the standard curve for total phenolics with known concentrations. The phenolic standard curve was determined by preparing pure phenol as standard in various concentrations. A 1000 ppm phenol stock solution was prepared and then diluted into a definite concentration, then read the absorbance with 21D Spectronic at $765 \mathrm{~nm}$.

\section{Data analysis}

Data that met the assumption of homogeneity and normality were analyzed using variance at a 5\% significant level and continued with Duncan's Multiple Range Test (DMRT) if the results were significant between treatments using SAS software and orthogonal polynomials test if there was an interaction. The maximum value of the two quantitative factors and the influence pattern was found by analyzing the Response Surface Method (RSM) using JAMP software. The surface plot model describes the distribution of the minimum and maximum area of the variable data displayed. Red color means the higher value, and green color means the lower. The relationships among factors were determined through Path analysis using Smartpls software shown on a path construction model.

\section{Results and Discussion}

The average daily ambient temperature measured during the experiment had a minimum range of $25.1-26.5^{\circ} \mathrm{C}$ and a maximum of 25.5-38.8 ${ }^{\circ} \mathrm{C}$, with an average humidity of $80.5 \%$ and a light intensity of 453 lux. The physical characteristics of soil used in the nursery had a pH of 5.23 (categorized as low), a $\mathrm{C} / \mathrm{N}$ ratio of 28.56 (very high), a total Ca of $42.18 \mathrm{mg} \mathrm{kg}^{-1}$ (very low), cation exchange capacity of 26.75 (high) and basicity saturation of 22.65 (low), according to a technical instruction for chemical soil, plants, water, and fertilizers analyses (Balittanah, 2008). The results of measuring the FTSW target weight in the field was a permanent wilt point of $11.055 \mathrm{~kg}$ resulting in the FTSW target weight of $0,0.35$, and 0.15 . Based on the equation, the soil water content (SWC) in the field capacity was $46.9 \%$, SWC in FTSW 0.35 was $32.66 \%$, SWC in FTSW 0.15 was $28.28 \%$ and SWC in permanent wilt point was $25 \%$. The mean leaf water potential at field capacity was $-0.49 \mathrm{MPa},-1.55 \mathrm{MPa}$ at FTSW 0.35 (moderate drought), and $-2.88 \mathrm{MPa}$ at FTSW 0.14 (severe drought).

\section{Hydrogen peroxide $\left(\mathrm{H}_{2} \mathrm{O}_{2}\right)$ content}

The $\mathrm{H}_{2} \mathrm{O}_{2}$ content is a variable that can be measured to determine the level of oxidative damage during drought stress. The results of the analysis of variance showed that there was an interaction effect between $\mathrm{Ca}$ dose and drought stress on $\mathrm{H}_{2} \mathrm{O}_{2}$ concentration (Table 1). The $\mathrm{H}_{2} \mathrm{O}_{2}$ concentration of leaf of oil palm without $\mathrm{Ca}$ 
gripped by moderate and severe drought significantly higher than the control. This condition indicates that drought stress has resulted in the accumulation of free radicals in leaves and increased in line with stress intensity. The response surface model (RSM) (Figure 1) can be displayed as follows :

$\mathrm{H}_{2} \mathrm{O}_{2}=105.69+(-161.37) *$ Calcium $+(-$ $1.904) * \mathrm{SWC}+($ Calcium 0.06$) *($ Calcium 0.06$) *$ $4010.55+($ Calcium 0.06$) *($ SWC 35.86$) * 15.00+$ $(\mathrm{SWC} 35.96) *(\mathrm{SWC} 35.96) * 0.062$

Based on the model, the $\mathrm{H}_{2} \mathrm{O}_{2}$ value will be the maximum (76.78 ppm) if the seedlings without $\mathrm{Ca}$ are given at the SWC of $28.3 \%$. In comparison, the $\mathrm{H}_{2} \mathrm{O}_{2}$ value will be the minimum (14.10 ppm) at the SWC $46.9 \%$ with $\mathrm{Ca}$ at $0.059 \mathrm{~g}$.

The increase in $\mathrm{H}_{2} \mathrm{O}_{2}$ occurs due to differences in $\mathrm{CO}_{2}$ concentrations when plants experience drought and limit the stomata to open. Drought causes an increase in ABA, resulting in a decrease in the opening of the stomata and limits the entry of $\mathrm{CO}_{2}$ into the leaf (Fathi \& Tari, 2016). When the amount of $\mathrm{CO}_{2}$ in the chloroplast is limited, electrons for $\mathrm{CO}_{2}$ assimilation in the Calvin cycle decrease. Excess electrons are diverted for other purposes (photorespiration) to dissipate heat due to increasing temperature (Suresh et al., 2012). If the electrons start to saturate, they will be transferred to oxygen in the PSI via Mehler's reaction. This process results free radicals such as superoxide, hydrogen peroxide $\left(\mathrm{H}_{2} \mathrm{O}_{2}\right)$, and $\mathrm{OH}^{-}$radicals which can cause oxidative damage (Silva et al., 2016). It had been previously reported by Nurwahyuni \& Putra (2019) that the addition of $0.08 \mathrm{~g}$ calcium significantly reduces stomatal closure in moderate and severe drought conditions by decreasing the ABA concentration. The mechanism allows $\mathrm{CO}_{2}$ to remain in and limits the oxidative damage evident from the high total chlorophyll and carotenoid content and further causes a high photosynthesis rate.

\section{Malondialdehyde (MDA) content}

The accumulation of reactive oxygen species (ROS) triggers lipid peroxidation in the cell membrane if the rate of antioxidant activity is lower than the accumulation of ROS. MDA is the end product of the peroxidation of unsaturated fatty acids in phospholipid membranes. MDA has the potential role to cause membrane damage includes changes in membrane structure, liquidity, ion transport, enzyme activity, and relationships between proteins to membrane leakage (Sharma et al., 2012). The amount of lipid peroxidation due to free radicals can indicate oxidative damage at the cellular level (Shukla et al., 2012).

Analysis of variance showed that there was no interaction effect between $\mathrm{Ca}$ application and drought treatments on MDA. Each factor influenced independently MDA content of oil palm seedlings (Table 2). MDA content was significantly higher in severe stress than in control, but it was not significantly different in moderate stress. In moderate stress, the MDA content tended to be higher but not significantly different than the control. This condition indicated that the plants respond to drought stress by increasing MDA, which significantly increased under heavy stress. The responses were also shown in MDA with various doses of $\mathrm{Ca}$. The MDA content in leaves with a dose of $0.08 \mathrm{~g} \mathrm{Ca}$ was significantly lower than the MDA content at a dose of $0.04 \mathrm{~g}$ and 0.12 $\mathrm{g} \mathrm{Ca}$. However, it was not significantly different from the control. The results indicated that $0.08 \mathrm{~g}$ of $\mathrm{Ca}$ application reduced MDA content significantly to a concentration of $6838.14 \mu \mathrm{mol} \mathrm{g}$ 1 . It showed that the plants positively responded to $\mathrm{Ca}$, especially at a concentration of $0.08 \mathrm{~g}$ indicated by the lower MDA content. The response surface model (RSM) (Figure 2) can be displayed as follow :

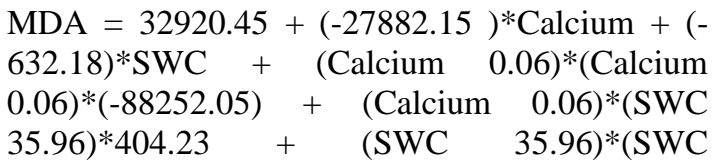
$35.96) * 34.106$

Based on the model, the MDA value will be the

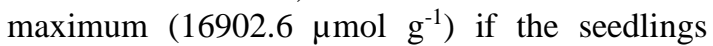
without $\mathrm{Ca}$ are at $28.3 \%$ SWC. In comparison, the MDA value will be the minimum $(8509.74 \mu \mathrm{mol}$ $\mathrm{g}^{-1}$ ) at SWC conditions $35.97 \%$ with Ca giving of $0.06 \mathrm{~g}$. As previously reported by Xu et al. (2013), $\mathrm{Ca}$ induced an increase in antioxidant enzymes and decreased MDA content in response to drought stress. In addition, it is suspected that the low MDA in $\mathrm{Ca}$ treatment was in line with the low concentration of $\mathrm{H}_{2} \mathrm{O}_{2}$ as the main product of ROS so that damage to the phospholipid membrane due to MDA can be avoided.

\section{Relative electrolyte leakage (REL)}

Tolerant plants have an enzymatic system that protects membrane lipids and membrane stability. In addition, plants have the ability to modify cell membranes by increasing the total pectin content with the addition of calcium, so that membrane damage due to ROS can be avoided (Nurwahyuni \& Putra, 2020). It was also reported by Sari \& Putra (2019) that the application of calcium was able to strengthen cell cohesiveness and increase the strength of the cell structure of oil palm seedling leaves that experience drought. The REL shows the relative amount of cellular fluid leakage caused by membrane damage due to oxidative stress. It is shown by membrane leakage (electrolyte leakage) measurement (Suresh, 2013). 
The role of calcium in drought stress response induced through antioxidant (Nurwahyuni \& Putra)

Table 1. $\mathrm{H}_{2} \mathrm{O}_{2}$ concentration (ppm) of oil palm leaf in response to several SWC and Ca doses

Tabel 1. Konsentrasi $\mathrm{H}_{2} \mathrm{O}_{2}$ ( ppm) daun kelapa sawit sebagai respons terhadap beberapa lengas tanah dan dosis $\mathrm{Ca}$

\begin{tabular}{ccccc}
\hline \multirow{2}{*}{$\begin{array}{c}\text { Ca dose }(\mathrm{g}) \\
\text { Dosis Ca }(\mathrm{g})\end{array}$} & \multicolumn{2}{c}{ Soil water content / lengas tanah $(\%)$} & \multirow{2}{*}{$\begin{array}{c}\text { Mean } \\
\text { Rata-rata }\end{array}$} \\
\cline { 2 - 4 } 0 & 46.9 & 32.7 & 28.3 & 54.41 \\
0.04 & $20.95 \mathrm{c}$ & $66.33 \mathrm{a}$ & $75.95 \mathrm{a}$ & 39.67 \\
0.08 & $18.93 \mathrm{c}$ & $47.71 \mathrm{abc}$ & $52.36 \mathrm{ab}$ & 26.39 \\
0.12 & $24.33 \mathrm{bc}$ & $32.56 \mathrm{bc}$ & $22.25 \mathrm{c}$ & $(+)$ \\
\hline Mean / Rata-rata & $24.30 \mathrm{bc}$ & $23.07 \mathrm{bc}$ & $64.58 \mathrm{a}$ & \\
\hline CV FTSW (\%) / KK FTSW (\%) & 22.13 & 42.43 & 53.78 & \\
CV Ca dose (\%) / KK Dosis Ca (\%) & & & 13.31 & 18.43 \\
\hline
\end{tabular}

${ }^{*}$ Means in the same column followed by the same letters are not significantly different according to Duncan's multiple range test at $\alpha=$ 0.05

${ }^{*}$ Angka dalam kolom yang sama diikuti oleh huruf yang sama berarti tidak berbeda nyata menurut uji jarak berganda Duncan pada $\alpha=$ 0,05

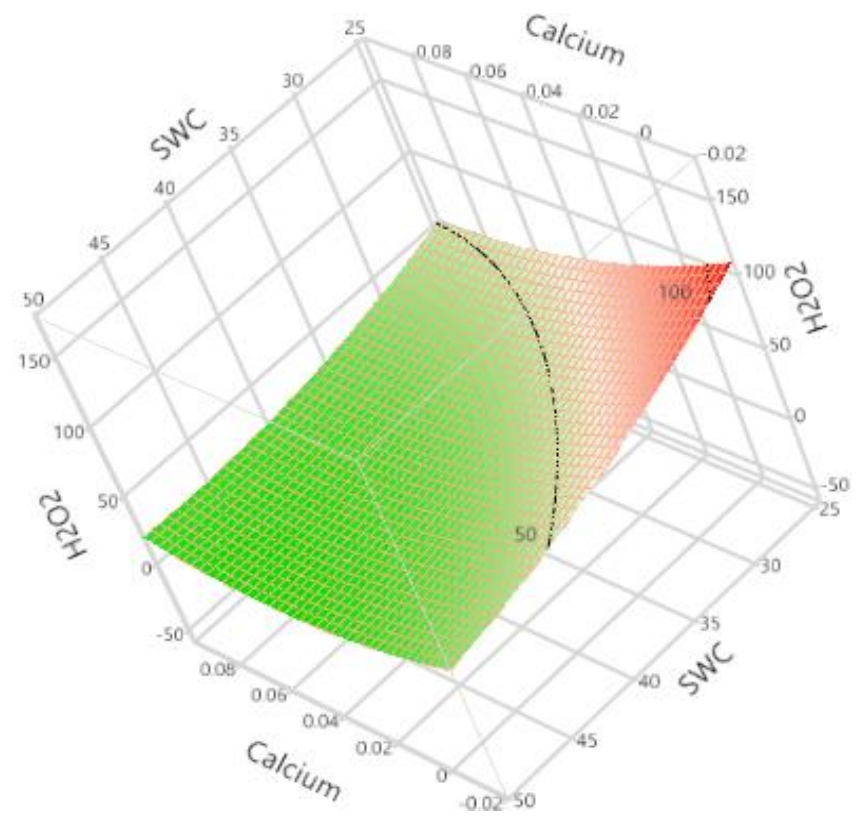

Figure 1. Response surface method (RSM) of $\mathrm{H}_{2} \mathrm{O}_{2}$ concentration

Gambar 1. Metode respons permukaan pada konsentrasi $\mathrm{H}_{2} \mathrm{O}_{2}$

Table 2. The concentration of MDA in oil palm seedling leaf treated with several SWC and Ca doses

Tabel 2. Konsentrasi MDA dalam daun bibit kelapa sawit pada beberapa lengas dan dosis Ca

\begin{tabular}{cc}
\hline SWC $(\%)$ & $\begin{array}{c}\text { MDA concentration }\left(\mu \mathrm{mol} \mathrm{g}^{-1}\right) \\
\text { Konsentrasi MDA }\left(\mu \mathrm{mol} \mathrm{g}^{-1}\right)\end{array}$ \\
\hline 46.9 & $5498.63 \mathrm{~b}$ \\
32.7 & $10762.54 \mathrm{ab}$ \\
28.3 & $15184.93 \mathrm{a}$ \\
\hline $\mathrm{CV}(\%) / \mathrm{KK}(\%)$ & 23.77 \\
\hline $\mathrm{Ca}$ dose $(\mathrm{g})$ & MDA concentration $\left(\mu \mathrm{mol}^{-1} \mathrm{~g}^{-1}\right)$ \\
Dosis Ca $(\mathrm{g})$ & Konsentrasi MDA $\left(\mu \mathrm{mol} \mathrm{g} \mathrm{g}^{-1}\right)$ \\
\hline 0 & $10937.94 \mathrm{ab}$ \\
0.04 & $14408.34 \mathrm{a}$ \\
0.08 & $6838.14 \mathrm{~b}$ \\
0.12 & $9743.72 \mathrm{ab}$ \\
\hline $\mathrm{CV}(\%) /$ KK $(\%)$ & 20.02 \\
\hline${ }^{*}$ Means in the column followed by the same letters are not significantly different according to Duncan's multiple range test at $\alpha=0.05$ \\
Angka dalam kolom yang diikuti oleh huruf yang sama berarti tidak berbeda nyata menurut uji jarak berganda Duncan pada $\alpha=0,05$
\end{tabular}




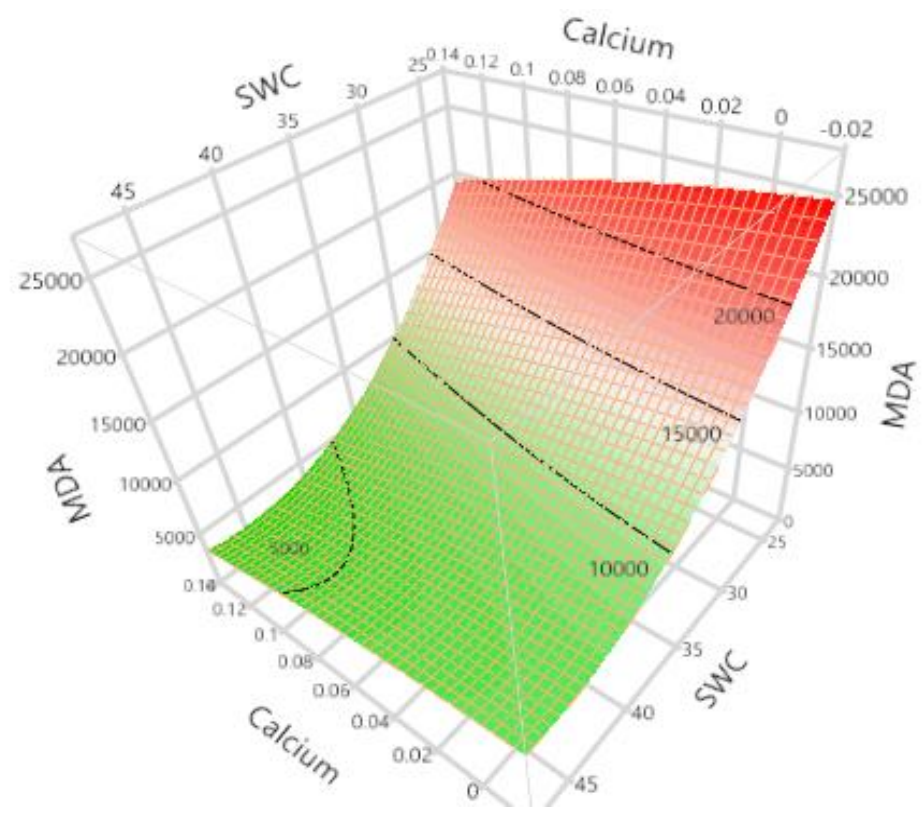

Figure 2. Response surface method (RSM) of MDA concentration Gambar 2. Metode respons permukaan pada konsentrasi MDA

The results of the analysis of variance showed that there was no interaction and there was no effect of the two factors on REL (Table 3). Although the increase in free radicals was significantly affected by drought stress and $\mathrm{Ca}$ dose, cell leakage was not significantly different. This result could not be explained in this study but based on path analysis, SWC was positively related to REL (Figure 4).

\section{Superoxide dismutase (SOD) activity}

The detoxification of free radicals in plants typically happens through enzymatic or nonenzymatic pathways. Carotenoids are known as non-enzymatic antioxidants that function to protect chlorophyll from oxidative damage. Turhadi et al. (2020) reported an increase in carotenoids in transgenic plants induced by drought using Polyethylene Glycol (PEG) as a plant drought tolerance response. Meanwhile, the SOD is an enzyme involved in the enzymatic mechanism to convert highly reactive superoxide radicals into less reactive $\mathrm{H}_{2} \mathrm{O}_{2}$ and $\mathrm{O}_{2}$ (Naeem et al., 2017). Therefore, the assessment of plant tolerance to abiotic stress is often characterized by increased SOD activity as a free radical scavenging agent.

The results of the analysis of variance indicated that there was an interaction effect between $\mathrm{Ca}$ doses and drought stress to the SOD value of oil palm leaf. Table 4 showed that for seedlings without $\mathrm{Ca}$, SOD activity in drought stress conditions was not different from field capacity. Further analysis showed a positive linear effect between SOD activity and Ca dose in the field capacity. The higher Ca given would increase SOD ctivity. Furthermore, the response surface model (RSM) (Figure 3) can be displayed as follow:

$\mathrm{SOD}=0.39+1.32 *$ Calcium $+(-0.00062 * \mathrm{SWC})$
$+\quad($ Calcium 0.06$) *($ Calcium 0.06$) *-73.74+$
$($ Calcium 0.06$) *($ SWC 35.96$) * 0.159+($ SWC
$35.96) *($ SWC 35.96$) * 0.001196$

The model above produces a prediction of the maximum SOD value $\left(0.37 \mathrm{U} \mathrm{ml}^{-1}\right)$ if the Ca dose given is $0.06 \mathrm{~g}$ at SWC $28.3 \%$ condition. In comparison, the SOD value will be a minimum $\left(0.1 \mathrm{U} \mathrm{ml}^{-1}\right)$ at SWC $28.3 \%$ condition without $\mathrm{Ca}$ addition. Superoxide is a free radical produced in photosystem I and II, which is then immediately converted into $\mathrm{H}_{2} \mathrm{O}_{2}$ by SOD due to stress. In the enzymatic mechanism, superoxide dismutase has a vital role in converting two molecules of superoxide into $\mathrm{O}_{2}$ and $\mathrm{H}_{2} \mathrm{O}_{2}$, which is the first step antioxidant system (Ahmad \& Haddad, 2011; Silva et al., 2016). According to Wang et al. (2018), increased SOD enzyme expression resulted in a better antioxidant system in plant chloroplasts.

\section{Total phenolic}

Phenolics are natural antioxidants in the flavonoid class produced by many plants when experiencing abiotic stress because of their role in neutralizing free radicals. In addition, phenolics play a role in strengthening cell wall bonds, so they are not easily damaged and degraded by peroxidase enzymes (Sahebi et al., 2017). Therefore, phenolic content can be used as an indicator to determine the level of plant resistance in responding to drought stress. 
The role of calcium in drought stress response induced through antioxidant..... (Nurwahyuni \& Putra)

Table 3. Relative electrolyte Leakage (REL) (\%) in oil palm seedling leaf Tabel 3. Kebocoran elektrolit relatif (REL) (\%) pada daun bibit kelapa sawit

\begin{tabular}{ccccc}
\hline \multirow{2}{*}{$\begin{array}{c}\text { Ca dose }(\mathrm{g}) \\
\text { Dosis Ca }(\mathrm{g})\end{array}$} & \multicolumn{2}{c}{ Soil water content / lengas tanah (\%) } & $\begin{array}{c}\text { Mean } \\
\text { Rata-rata }\end{array}$ \\
\cline { 2 - 4 } 0 & 46.9 & 32.7 & 28.3 & 86.28 \\
0.04 & $89.74 \mathrm{a}$ & $83.20 \mathrm{a}$ & $85.90 \mathrm{a}$ & 84.17 \\
0.08 & $86.57 \mathrm{a}$ & $83.70 \mathrm{a}$ & $82.24 \mathrm{a}$ & 86.20 \\
0.12 & $86.30 \mathrm{a}$ & $85.95 \mathrm{a}$ & $86.35 \mathrm{a}$ & $(-)$ \\
\hline Mean / Rata-rata & $84.42 \mathrm{a}$ & $75.13 \mathrm{a}$ & $89.01 \mathrm{a}$ & 82.85 \\
\hline CV FTSW (\%) / KK FTSW $(\%)$ & 86.75 & 82.00 & & \\
CV Ca dose (\%) / KK Dosis Ca $(\%)$ & & 4.15 & & \\
\hline
\end{tabular}

${ }^{*}$ Means in the same column followed by the same letters are not significantly different according to Duncan's multiple range test at $\alpha$ $=0.05$

${ }^{*}$ Angka dalam kolom yang sama diikuti oleh huruf yang sama berarti tidak berbeda nyata menurut uji jarak berganda Duncan pada $\alpha$ $=0,05$

Table 4. Activity of SOD $\left(\mathrm{U} \mathrm{mL}^{-1}\right)$ in the oil palm seedling leaf on several SWC and Ca doses

Tabel 4. Aktivitas SOD $\left(U \mathrm{~mL}^{-1}\right)$ dalam daun bibit kelapa sawit pada beberapa lengas tanah dan dosis Ca

\begin{tabular}{|c|c|c|c|c|}
\hline \multirow{2}{*}{$\begin{array}{l}\text { Ca dose }(\mathrm{g}) \\
\text { Dosis Ca }(g)\end{array}$} & \multicolumn{3}{|c|}{ Soil water content / lengas tanah (\%) } & \multirow{2}{*}{$\begin{array}{c}\text { Mean } \\
\text { Rata-rata }\end{array}$} \\
\hline & 46.9 & 32.7 & 28.3 & \\
\hline 0 & $-0.1387 b$ & $-0.1554 b$ & $-0.2264 b$ & -0.1735 \\
\hline 0.04 & $-0.4311 b$ & $0.3459 \mathrm{a}$ & $0.2080 \mathrm{ab}$ & 0.0409 \\
\hline 0.08 & $0.1454 \mathrm{ab}$ & $0.2832 \mathrm{a}$ & $0.2581 \mathrm{a}$ & 0.2289 \\
\hline 0.12 & $0.2957 \mathrm{a}$ & $-0.2431 b$ & $0.2707 \mathrm{a}$ & 0.1078 \\
\hline Mean / Rata-rata & -0.0322 & 0.0576 & 0.1276 & $(+)$ \\
\hline CV FTSW (\%) / KK FTSW (\%) & \multicolumn{4}{|c|}{40.32} \\
\hline CV Ca dose (\%) / KK Dosis Ca (\%) & \multicolumn{4}{|c|}{31.86} \\
\hline
\end{tabular}

${ }^{*}$ Means in the same column followed by the same letters are not significantly different according to Duncan's multiple range test at $\alpha=$ 0.05

${ }^{*}$ Angka dalam kolom yang sama diikuti oleh huruf yang sama berarti tidak berbeda nyata menurut uji jarak berganda Duncan pada $\alpha=$ 0,05

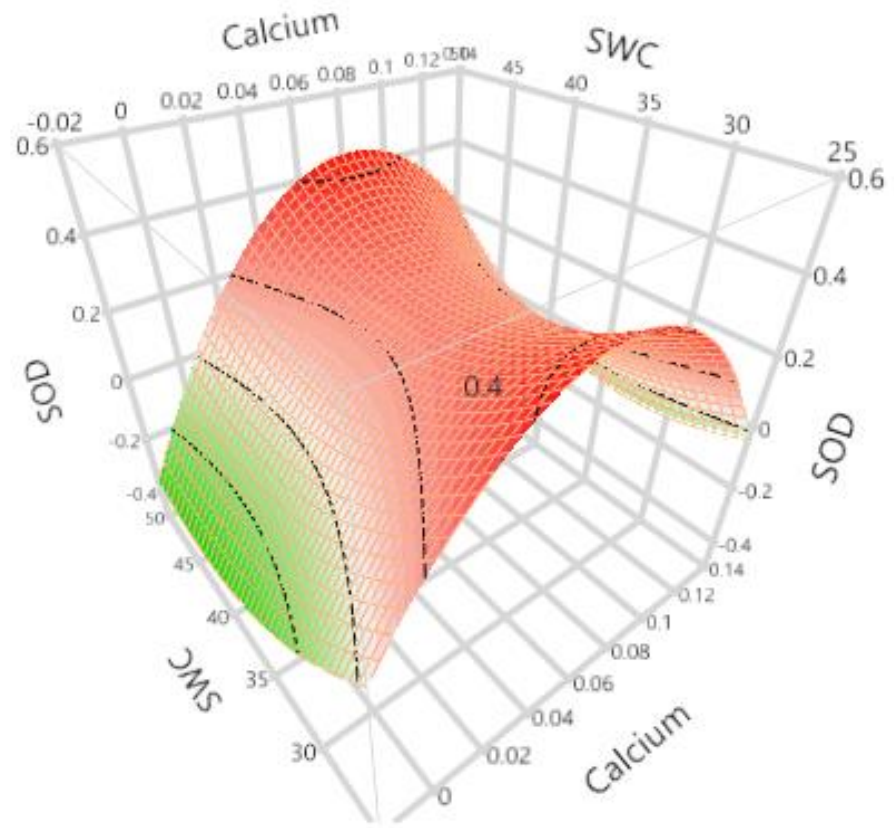

Figure 3. Response surface method (RSM) of SOD Gambar 3. Metode respons permukaan pada SOD 
The variance analysis showed no interaction between $\mathrm{Ca}$ dose and soil moisture content and no individual effect of $\mathrm{Ca}$ dose and soil moisture content on phenolic content (Table 5). However, the phenolic measurement resulted in the highest value at the lowest moisture content. It decreased according to the increase in moisture content. This condition illustrates the change in biochemical activity that leads to plant resistance through the antioxidant system. Furthermore, based on the path analysis in Figure 4, SWC had a negative relationship to the total phenolic.

Table 5. Effect of Ca and SWC on total phenolic content (ppm) in oil palm seedling leaf.

Tabel 5. Pengaruh Ca dan lengas tanah terhadap kandungan fenolik total (ppm) daun bibit kelapa sawit

\begin{tabular}{|c|c|c|c|c|}
\hline \multirow{2}{*}{$\begin{array}{c}\text { Ca dose }(\mathrm{g}) \\
\text { Dosis Ca }(g)\end{array}$} & \multicolumn{3}{|c|}{ Soil water content / lengas tanah (\%) } & \multirow{2}{*}{$\begin{array}{c}\text { Mean } \\
\text { Rata-rata }\end{array}$} \\
\hline & 46.9 & 32.7 & 28.3 & \\
\hline 0 & $59.76 \mathrm{a}$ & $68.40 \mathrm{a}$ & $58.34 \mathrm{a}$ & 62.17 \\
\hline 0.04 & $44.47 \mathrm{a}$ & $101.10 \mathrm{a}$ & $62.71 \mathrm{a}$ & 69.42 \\
\hline 0.08 & $55.39 \mathrm{a}$ & $83.93 \mathrm{a}$ & $96.26 \mathrm{a}$ & 78.53 \\
\hline 0.12 & $66.69 \mathrm{a}$ & $53.85 \mathrm{a}$ & $113.63 a$ & 78.06 \\
\hline Mean / Rata-rata & 56.58 & 76.82 & 82.73 & $(-)$ \\
\hline CV FTSW (\%) / KK FTSW (\%) & \multicolumn{4}{|c|}{28.83} \\
\hline CV Ca dose (\%) / KK Dosis Ca (\%) & \multicolumn{4}{|c|}{14.65} \\
\hline
\end{tabular}

${ }^{*}$ Means in the same column followed by the same letters are not significantly different according to Duncan's multiple range test at $\alpha=$ 0.05

${ }^{*}$ Angka dalam kolom yang sama diikuti oleh huruf yang sama berarti tidak berbeda nyata menurut uji jarak berganda Duncan pada $\alpha=$ 0,05

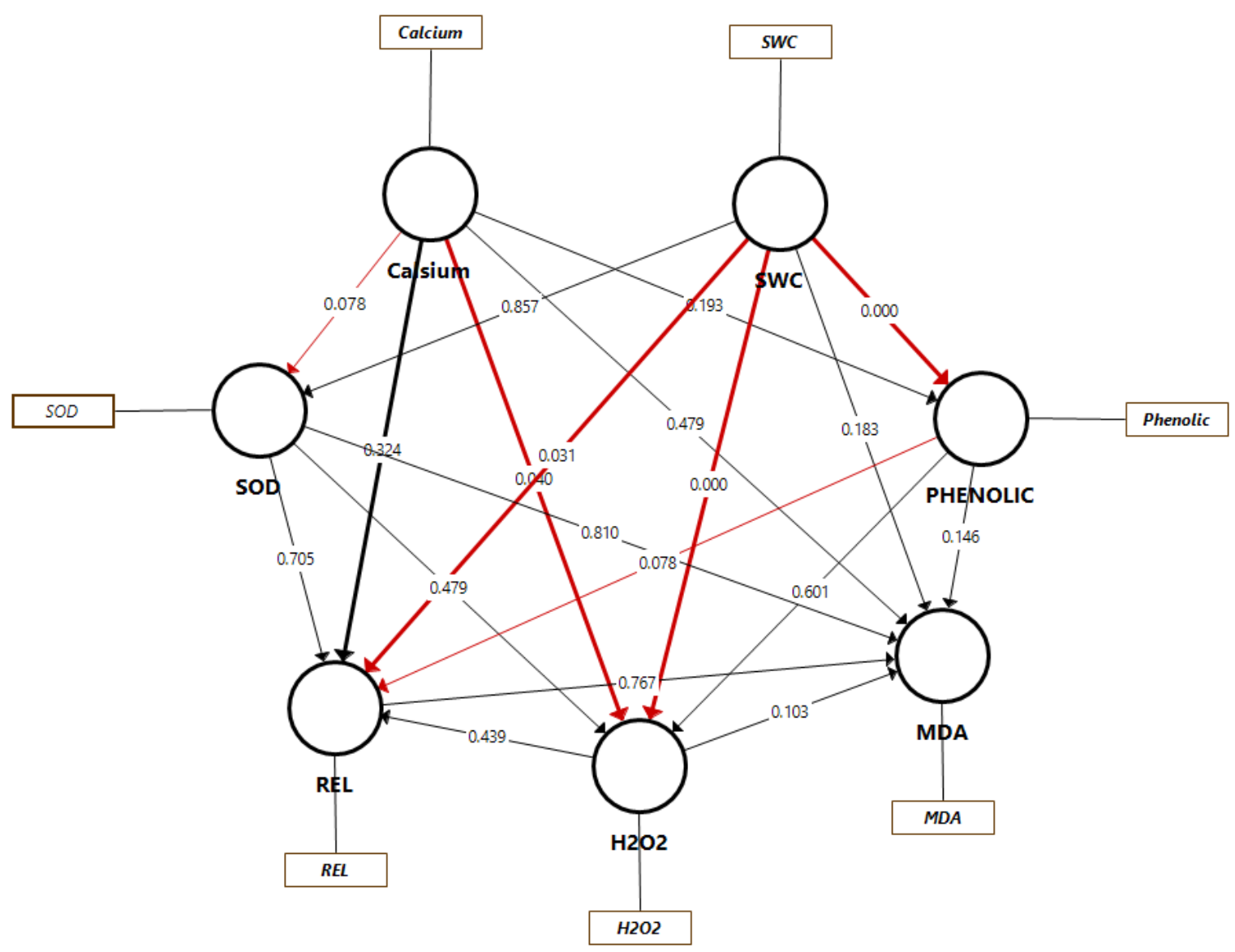

Figure 4. Path construction model

Gambar 4. Model konstruksi lintasan 
Table 6. Direction of relationship and p-value among variables

Tabel 6. Arah hubungan dan nilai-p antar variabel

\begin{tabular}{|c|c|c|c|c|c|}
\hline $\begin{array}{l}\text { Variabel / } \\
\text { Variabel }\end{array}$ & $\begin{array}{l}\text { Original } \\
\text { Sample } \\
\text { Sampel } \\
\text { Original } \\
\text { (O) }\end{array}$ & $\begin{array}{l}\text { Sample Mean } \\
\text { Rata-rata } \\
\text { Sampel } \\
\text { (M) }\end{array}$ & $\begin{array}{l}\text { Standard deviation } \\
\text { Standar Deviasi } \\
\text { (STDEV) }\end{array}$ & $\begin{array}{c}\text { T Statistics } \\
\text { Statistik T } \\
(|\mathrm{O} / \mathrm{STDEV}|)\end{array}$ & $\begin{array}{c}\text { p-value at } \alpha \\
=5 \% / \text { Nilai } \\
\text { p pada } \alpha= \\
5 \%\end{array}$ \\
\hline Calcium $\rightarrow \mathrm{H}_{2} \mathrm{O}_{2}{ }^{*}$ & -0.294 & -0.301 & 0.139 & 2.123 & 0.034 \\
\hline Calcium $\rightarrow$ MDA & -0.139 & -0.173 & 0.200 & 0.696 & 0.487 \\
\hline Calcium $\rightarrow$ PHENOLIC & 0.182 & 0.176 & 0.135 & 1.342 & 0.180 \\
\hline Calcium $\rightarrow$ REL & -0.223 & -0.218 & 0.228 & 0.982 & 0.327 \\
\hline Calcium $\rightarrow$ SOD & 0.237 & 0.244 & 0.132 & 1.800 & 0.072 \\
\hline $\mathrm{H}_{2} \mathrm{O}_{2} \rightarrow \mathrm{MDA}$ & 0.328 & 0.328 & 0.209 & 1.567 & 0.118 \\
\hline $\mathrm{H}_{2} \mathrm{O}_{2} \rightarrow \mathrm{REL}$ & 0.171 & 0.157 & 0.229 & 0.746 & 0.456 \\
\hline PHENOLIC $\rightarrow \mathrm{H}_{2} \mathrm{O}_{2}$ & 0.075 & 0.064 & 0.144 & 0.521 & 0.603 \\
\hline PHENOLIC $\rightarrow$ MDA & 0.268 & 0.249 & 0.180 & 1.491 & 0.137 \\
\hline PHENOLIC $\rightarrow$ REL & 0.351 & 0.338 & 0.203 & 1.731 & 0.084 \\
\hline $\mathrm{REL} \rightarrow \mathrm{MDA}$ & -0.051 & -0.072 & 0.167 & 0.307 & 0.759 \\
\hline $\mathrm{SOD} \rightarrow \mathrm{H}_{2} \mathrm{O}_{2}$ & -0.112 & -0.086 & 0.145 & 0.772 & 0.441 \\
\hline $\mathrm{SOD} \rightarrow \mathrm{MDA}$ & -0.025 & -0.020 & 0.101 & 0.245 & 0.807 \\
\hline $\mathrm{SOD} \rightarrow \mathrm{REL}$ & 0.075 & 0.060 & 0.203 & 0.370 & 0.712 \\
\hline $\mathrm{SWC} \rightarrow \mathrm{H}_{2} \mathrm{O}_{2}{ }^{*}$ & -0.523 & -0.534 & 0.138 & 3.781 & 0.000 \\
\hline $\mathrm{SWC} \rightarrow \mathrm{MDA}$ & -0.266 & -0.267 & 0.197 & 1.352 & 0.177 \\
\hline SWC $\rightarrow$ PHENOLIC ${ }^{*}$ & -0.445 & -0.449 & 0.106 & 4.220 & 0.000 \\
\hline $\mathrm{SWC} \rightarrow \mathrm{REL}^{*}$ & 0.476 & 0.477 & 0.235 & 2.021 & 0.044 \\
\hline $\mathrm{SWC} \rightarrow \mathrm{SOD}$ & -0.032 & -0.015 & 0.173 & 0.184 & 0.854 \\
\hline
\end{tabular}

Note: Calcium $=\mathrm{Ca}$ dose $; \mathrm{H}_{2} \mathrm{O}_{2}=$ hydrogen peroxide content MDA = malondialdehyde content PHENOLIC = total phenolic; REL = relative electrolyte leakage; SOD = superoxide dismutase activity; asterisk $(*)$ showed direct relationship between variables at significance level $(\alpha)=5 \%$

Keterangan: Calcium $=$ dosis $\mathrm{Ca} ; \mathrm{H}_{2} \mathrm{O}_{2}=$ konsentrasi hidrogen peroksida $;$ MDA $=$ kandungan malondialdehid $;$ PHENOLIC $=$ konsentrasi fenol total; $R E L=$ kebocoran elektrolit relatif; $S O D=$ aktivitas superoksida dismutase; tanda bintang (*) menunjukkan hubungan langsung yang signifikan antar variable pada taraf nyatai $(\alpha)=5 \%$

\section{Conclusion}

This study proved that drought resulted in changes in biochemical activity characterized by increased $\mathrm{H}_{2} \mathrm{O}_{2}$ and MDA (free radicals) in leaf of oil palm seedling. Calcium with a dose range of $0.04-0.08 \mathrm{~g}$ reduced the rate of free radicals by increasing the activity of SOD as an enzymatic antioxidant. The optimal effect of calcium on the biochemical mechanisms can be obtained at $0.06 \mathrm{~g}$ plant $^{-1}$.

\section{Acknowledgments}

The researchers deliver their gratitude to Gadjah Mada University and The Indonesia Endowment Fund for Education (LPDP) for providing the fund to this research.

\section{References}

Ahmad AR, J Juwita, SAD Ratulangi \& A Malik (2015). Penetapan kadar fenolik dan flavonoid total ekstrak metanol buah dan daun patikala
(Etlingera elatior (Jack) R.M.SM). Pharmaceutical Sci Res 2(1), 1-10.

Ahmad P, R Bhardwaj \& N Tuteja (2012). Plant signaling under abiotic stress environment. In: Ahmad P \& M Prasad (eds.), Environmental Adaptations and Stress Tolerance of Plants in the Era of Climate Change. New York, Springer. p. 297-323.

Ahmad ST \& R Haddad (2011). Study of silicon effects on antioxidant enzyme activities and osmotic adjustment of wheat under drought stress. Czech J Genet Plant Breed 47(1), 1727.

Alexieva V, I Sergiev, S Mapelli \& E Karanov (2001). The effect of drought and ultraviolet radiation on growth and stress markers in pea and wheat. Plant Cell Environ 24(12), 13371344.

Amanah DM, Nurhaimi-Haris \& LP Santi (2019). Physiological responses of bio-silica-treated 
oil palm seedlings to drought stress. Menara Perkebunan 87(1), 20-30.

Aroca DR (2012). Plant Responses to Drought Stress from Morphological to Molecular Features. Granada, Springer.

Ashraf M \& PJC Harris (2013). Photosynthesis under stressful environments: an overview. Photosynthetica 51(2), 163-190.

Balittanah (2008). Petunjuk Teknis Analisis Kimia Tanah, Tanaman, Air dan Pupuk. Bogor, Balai Penelitian Tanah.

Cheng-xu S, C Hong-xing, S Hong-bo, L Xin-tao $\&$ X Yong (2011). Growth and physiological responses to water and nutrient stress in oil palm. Afr J Biotechnol 10(51), 10465-10471.

Darlan NH, I Pradiko, Winarna \& HH Siregar (2016). Effect of El Nino 2015 on oil palm performance in Southeastern Part of Sumatera. Indonesian Soil Climate J 40(2), 113-120.

Dionisio-Sese ML \& S Tobita (1998). Antioxidant responses of rice seedlings to salinity stress. Plant Sci 135(1), 1-9.

Laanemets K, B Brandt, J Li, E Merilo, YF Wang, MM Keshwani, SS Taylor, H Kollist \& JI Schroeder (2013). Calcium-dependent and independent stomatal signaling network and compensatory feedback control of stomatal opening via $\mathrm{Ca}^{2+}$ sensitivity priming. Plant Physiol 163(2), 504-513.

Liebenberg A, JR van der Nest, AG Hardie, J Labuschagne \& PA Swanepoel (2020). Extent of soil acidity in no-tillage systems in the Western Cape Province of South Africa. Land 9(10), 361.

Marklund S \& G Marklund (1974). Involvement of the superoxide anion radical in the autoxidation of pyrogallol and a convenient assay for superoxide dismutase. Eur J Biochem 47(3), 469-474.

Mckersie BD, SR Bowley, E Harjanto, \& O Leprince (1996). Water-deficit tolerance and field performance of transgenic alfalfa overexpressing superoxide dismutase. Plant Physiol 111(4), 1177-1181.

Meng LL, JF Song, J Wen, J Zhang \& JH Wei (2016). Effects of drought stress on fluorescence characteristics of photosystem II in leaves of Plectranthus scutellarioides. Photosynthetica 54(3), 414-421.

Ministry of Agriculture, Republic of Indonesia (2017). Tree Crop Estate Statistics of Indonesia 2015-2017 Palm Oil. Jakarta, Secretariate of Directorate General of Estate Crops.
Naeem M, MS Naeem, R Ahmad \& R Ahmad (2017). Foliar-applied calcium induces drought stress tolerance in maize by manipulating osmolyte accumulation and antioxidative responses. Pak J Bot 49(2), 427-434.

Nurwahyuni E \& ETS Putra (2020). Penambahan kalsium meningkatkan kandungan pektin pada bibit kelapa sawit tercekam kekeringan (Elaeis guineensis Jacq.). J Pen Kelapa Sawit 28(3), 169-178.

Nurwahyuni E \& ETS Putra (2019). The effect of calcium on photosynthetic rate due to ABA and proline behaviour of oil palm (Elaeis guineensis jacq.) seedlings under drought conditions. J Sustain Agric 34(1), 31-42.

Putra ETS, Issukindarsyah, Taryono \& BH Purwanto (2015). Physiological responses of oil palm seedlings to the drought stress using boron and silicon applications. J Agron 14(2), 49-61.

Ray JD \& TR Sinclair (1998). The effect of pot size on growth and transpiration of maize and soybean during water deficit stress. J Exp Bot 49(325), 1381-1386.

Safitri L, S Suryanti, V Kautsar, A Kurniawan \& F Santiabudi (2018). Study of oil palm root architecture with variation of crop stage and soil type vulnerable to drought. IOP Conf Ser: Earth Environ Sci 141, 012031.

Sahebi M, MM Hanafi, AJ van Wijnen, ASN Akmar, P Azizi, AS Idris, S Taheri \& M Foroughi (2017). Profiling secondary metabolites of plant defence mechanisms and oil palm in response to Ganoderma boninense attack. Int Biodeterior Biodegradation 122, 151-164.

Sari NY \& ETS Putra (2019). The contribution of calcium to changes in leaf anatomical character of oil palm seedlings (Elaeis guineensis Jacq.) under drought stress. Agric Sci 4(1), 23-32.

Sharma P, AB Jha, RS Dubey \& M Pessarakli (2012). Reactive oxygen species, oxidative damage, and antioxidative defense mechanism in plants under stressful conditions. J Bot 217037.

Shekari F, V Soltaniband, A Javanmard \& A Abbasi (2015). The impact of drought stress at different stages of development on water relations, stomatal density and quality changes of rapeseed (Brassica napus L.). Iran Agric Res 34(2), 81-90.

Shukla N, RP Awasthi, L Rawat \& J Kumar (2012). Biochemical and physiological responses of rice (Oryza sativa L.) as influenced by Trichoderma harzianum under drought stress. Plant Physiol Biochem 54, 78- 
88.

Silva PA, IV Oliveira, KCB Rodrigues, VS Cosme, AJR Bastos, KSC Detmann, RL Cunha, RA Festucci-Buselli, FM DaMatta \& HA Pinheiro (2016). Leaf gas exchange and multiple enzymatic and non-enzymatic antioxidant strategies related to drought tolerance in two oil palm hybrids. Trees 30(1), 203-214.

Singh HCP, KS Shivashankara \& NKS Rao (2013). Climate-Resilient Horticulture: Adaptation and Mitigation Strategies. New Delhi, Springer.

Suresh K, C Nagamani, DL Kantha \& MK Kumar (2012). Changes in photosynthetic activity in five common hybrids of oil palm (Elaeis guineensis Jacq.) seedlings under water deficit. Photosynthetica 50(4), 549-556.
Turhadi, H Minarsih, I Riyadi, Priyono \& A Budiani (2020). Physiological responses and P5CS gene expression of transgenic oil palm plantlet induced by drought stress. Menara Perkebunan 88(2), 69-78.

Wang Z, G Li, H Sun, L Ma, Y Guo, Z Zhao, H Gao \& L Mei (2018). Effects of drought stress on photosynthesis and photosynthetic electron transport chain in young apple tree leaves. Biol Open 7(11), 1-9.

Xu C, X Li, \& L Zhang (2013). The effect of calcium chloride on growth, photosynthesis, and antioxidant responses of Zoysia japonica under drought conditions. PLOS ONE 8(7), 110.

Zhu J (2016). Review abiotic stress signaling and responses in plants. Cell 167(2), 313-324. 